\title{
医菄品の配合変化に関する研究 抗生物澌シロップ绪*1
}

高杉益充, 宮田一好, 梅田 宗, 板東幸隆, 水口和生 ${ }^{* 2}$

徳島大学医学部付属病院薬剤部 $* 2$

\section{Incompatibility Between Antibiotics and Other Ingredients in Syrup*1}

\author{
MASUmitsu TAKASUgi, KazUYoshi Miyata, Hazime Umeda, \\ YUKITAKA BANDO, and KAZUO MINAGUCHI*2 \\ Department of Pharmacy, Tokushima University Hospital*2
}

\begin{abstract}
Incompatibility between 8 kinds of antibiotics and 9 frequently used drugs in syrups was studied on the basis of dispersion of ingredients. 80 combinations of mixtures of antibiotics and other agents were examined. Water was added to make $30 \mathrm{ml}$ of mixture in a test tube. Precipitation and dispersion of ingredients were observed, turning the test tube upside down at a regular interval at the temperature of $8^{\circ}$ and $30^{\circ}$. 9 of the 80 combinations showed complete final dispersion after more than 20 -time inversion of the test tube.
\end{abstract}

\section{は じめに}

シロップ剂は本来原液のまま単味で投与される阂型で あると考えるが，わが国では古くからの習慣で他の薬剤 を配合したり，水で希釈して投与されることが多い。そ のためにときに配合変化や再分散性に問題を生ずること がある.

そこで今回著者らは，抗生物質のシロップ剂について 再分散性に重点をおき配合の可否を検討した。

\section{实 方 法}

表 1 に示す德島大学病院において, 繁用されている抗 生物質のドライシロップ斉 8 品目（調阂 No. 1 ～8）

と，抗生物質と配合されることが多いとみられる液剤な らびに散阂 9 品目（調剤 No. 9１7）を選定し，それぞ れを個々に配合し，水を加えて全量を $30 \mathrm{~m} \ell$ として観察 した.なお，この配合量は 3 才児平均体重 $13 \mathrm{~kg}$ の 1 日 常用量である.

使用した水の $\mathrm{pH}$ は 6.8 である.

まず, 表 1 に示した配合量の 2 倍量をそれぞれとり， スターラーで 1 分間擤汼し，直ちに $\mathrm{pH}$ を測定し，つい で試料を 2 本の共栓硬質試験管に移し， 1 本を $30^{\circ}$ に, 他の 1 本を $8^{\circ}$ に静置する. その後 $30^{\circ}$ のものについて は直後, 3 時間後, 24 時間後, 3 日後, 7 日後の沈澱

\footnotetext{
*1 1975年度中国四国薬学会にて発表

*2 徳島市蔵本町 2 丁目 $50 ; 50$, Kuramotocho

2-chome, ToKushima-shi, 770 Japan.
}

表 1 配合薬の種類と量

\begin{tabular}{|c|c|c|c|c|}
\hline $\begin{array}{c}\text { 調放 } \\
\text { No. }\end{array}$ & 薬㫛 & 量 & Lot $\mathrm{Na}$ & 会社名 \\
\hline 1 & エリスロシンドライシロップ & & & \\
\hline 2 & ケフレックス細 粒 & & & シオノギ \\
\hline 3 & 七ポールドライシロップ & $00 \mathrm{mg}$ & & 鳥 \\
\hline 4 & ソルシリン 顆 粒 & mg & 00 & 武 \\
\hline 5 & バストシリン細粒 & mg & & 武 \\
\hline 6 & パセトシン細 粒 & 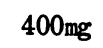 & DK & 協和 \\
\hline 7 & ビク & & & \\
\hline 8 & ビブラマイシン ドライシロップ & $40 \mathrm{mg}$ & $\begin{array}{r}581231 \\
W\end{array}$ & \\
\hline 9 & フスペリンシロップ & $\mathrm{m} \ell$ & & 田 \\
\hline 10 & イノリンシロップ & nl & & 田 \\
\hline 11 & スルピリン 末 & mg & $\mathrm{Dx}$ & 第 \\
\hline 12 & ビソルボン 液 & $l$ & 1 & 田 \\
\hline 13 & フラビタンシロッブ & $3 \mathrm{ml}$ & & 山之内 \\
\hline 14 & ペリアクチンシロップ & & & 萬 \\
\hline 15 & ポ ポ ン & ll & $\mathrm{Z} 210 \mathrm{Z}$ & シオノギ \\
\hline 16 & メチルェフェドリン散 & $30 \mathrm{mg}$ & カ401230 & 田 \\
\hline 17 & レフトーゼシロップ & $\mathrm{m} \ell$ & 682 & 日本 \\
\hline
\end{tabular}

の状態および夜層部の色調を観察し，また 7 日後味・臭 いの観察ならびに再分散性と $\mathrm{pH}$ を測定した。

$8^{\circ}$ 保存のものについては，7 日後に再分散性と $\mathrm{pH}$ を 測定し，また，すべてについて $30^{\circ}$ 保存のものと比較し た.これは夏期と冬期で投与後の状態が異なるかどうか を考虑したものである. 


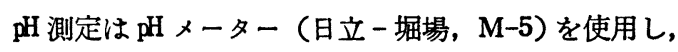
スターラーは Toyo, V 25 を用いた. スターラーによる 锶汼法を採用したのは, 振盜法に比べて, 調剂後の泡立 ちが少く観察しやすいためである.

再分散性は，図 1 のように共栓試 験管の上部に高さ $10 \mathrm{~mm}$ 程度の空気層を残して試料を入れ，これを 7 日間 静置した後, 静かに倒立させてまた元の状態に戻す操作 をくり返し，沈澱物が再分散し，均一な䊬濁液になるま での回数で表示した.

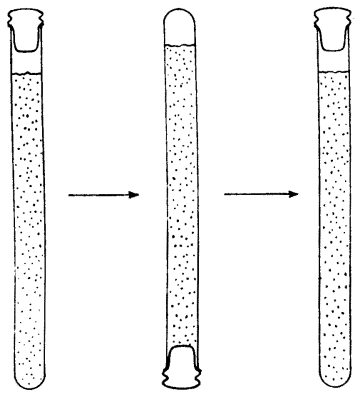

図 1 再分散性の実験方法
この方法で測定した 回数が 10 回を越える場合には, 投薬瓶で穾際に患者に投与した場合の再分散性が悪いと いえる. 20 回を越える場合には，患者が底に沈澱した主 成分を服用しない恐れがある.これは実際に投薬瓶と試 験管について比較実験して得た結果から判断したもので ある.

\section{实 路 果}

抗生物質個々についての結果を表 2-a〜表 2-h に示 す. 表中の憅濁状態の表現はつぎの通りである。

(1) : 分離などの不均一な状態を示さない.

(2)：上部に透明な部分を生じた.

(3) : 底部に沈澱を生じた。

一 $\mathrm{a}$ : 全体にも細かい浮遊物がある.

一b : 全体に大大い浮遊物がある.

一c：沈澱以外はほぼ透明である。

一 $\mathrm{d}$ : 上部にす大きい浮遊物がある.

一 : 沈澱以外は均一な懸濁状態である.

(4): 一部の粒子は浮上している.

(5) : 完全に透明である.

表 2-a エリスロシンドライシロップの実験結果

\begin{tabular}{|c|c|c|c|c|c|c|c|c|c|c|c|c|c|c|c|}
\hline エリスロシンに对して & \multicolumn{2}{|c|}{ p H } & \multicolumn{4}{|c|}{ 䋰濯の状態, $30^{\circ}$} & \multicolumn{4}{|c|}{ 液層部の色, $30^{\circ}$} & \multicolumn{5}{|c|}{7 日 後 の } \\
\hline 配 合 剂 & 直後 & 7日後 & \begin{tabular}{r|} 
間時 \\
\end{tabular} & 1日後 & 3日後 & 7日後 & 直後 & 1日後 & 3日後 & 7日後 & 味·奥 & \begin{tabular}{|c} 
再仯散 \\
$30^{\circ}$ \\
\end{tabular} & \begin{tabular}{|c|} 
再分散 \\
$8^{\circ}$ \\
\end{tabular} & 冷 $\longrightarrow$ & 温 \\
\hline L & 8.2 & 7.6 & (3)- d & 全体: & - & (3)-c $-d$ & ピンク & - & - & - & 葓い & 2 & 2 & (色調) & $\begin{array}{l}\text { (状態) } \\
\text { (3) }-c \rightarrow \text { (3)- }-\mathrm{c}\end{array}$ \\
\hline アスベリンシロップ & 6.8 & 6.6 & (1) & 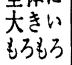 & - & (3) $-\mathrm{c}$ & オレンシ & - & - & - & $"$ & 1 & 0 & - & (1) $\rightarrow$ (3)-c \\
\hline イノリンシロップ & 6.4 & 6.2 & (3)- d & - & - & $\begin{array}{l}\text { (3) }-c \\
\text { (3) }-d\end{array}$ & ピンク & - & - & - & $"$ & 2 & 2 & - & - \\
\hline スルピリン & 8.2 & 7.6 & (3) - d & - & - & $\begin{array}{l}(3)-c \\
\text { (3) }-d\end{array}$ & " & - & - & - & $"$ & 2 & 2 & - & - \\
\hline ビソルボン液 & 7.0 & 6.8 & (3)- d & - & - & $\begin{array}{l}\text { (3) }-c \\
\text { (3) }-d\end{array}$ & $"$. & - & - & 無色 & $"$ & 2 & 2 & ピンクー無色 & - \\
\hline フラビタンシロップ & 7.5 & 7.2 & (3) $-d$ & - & - & $\begin{array}{l}\text { (3) }-c \\
\text { (3) }-d\end{array}$ & オレシ: & - & - & - & $" \prime$ & 3 & 2 & - & - \\
\hline ペリアクチンシロップ & 7.2 & 7.1 & (3)- d & - & - & $\begin{array}{l}\text { (3) }-c \\
\text { (3)- }-d\end{array}$ & ピンク & - & - & 無色 & $"$ & 2 & 2 & - & - \\
\hline ポポン $\mathrm{S}$ 液 & 6.1 & 6.0 & (3)- d & (3)- $a$ & - & (3) $-c$ & オレシジ & - & - & - & " & 3 & 4 & - & - \\
\hline メチルエフェドリン散 & 8.0 & 7.6 & (3)- $d$ & - & - & $\begin{array}{l}\text { (3) }-c \\
\text { (3) }-d\end{array}$ & ピンク & - & - & 無色 & $" \prime$ & 3 & 2 & ピンク 無色 & (3) $-c \rightarrow(3)-c$ \\
\hline レクトーゼシロップ & 7.9 & 7.4 & (3) $-d$ & - & - & $\begin{array}{l}(3)-c \\
(3)-d\end{array}$ & $"$ & - & - & $"$ & $"$ & 2 & 3 & $" \prime$ & - \\
\hline
\end{tabular}

注：表中の一はその前の状態と比して変化していないことを示す。

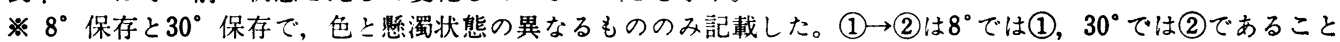
を示す。 
表 2-b ケフレックス細精の実験結果

\begin{tabular}{|c|c|c|c|c|c|c|c|c|c|c|c|c|c|c|c|}
\hline ケフレックスに対して & \multicolumn{2}{|c|}{$\mathrm{pH}$} & \multicolumn{4}{|c|}{ 懸濁の状態， $30^{\circ}$} & \multicolumn{4}{|c|}{ 液層部の色， $30^{\circ}$} & \multicolumn{5}{|c|}{7 日 後 の } \\
\hline 配 合 剂 & 直後 & 7 日後 & \begin{tabular}{|c|}
3 時 \\
間後
\end{tabular} & 1日後 & 3日後 & 7日後 & 㨁後 & 1日後 & 3日後 & 7 日後 & 味·臭 & $\begin{array}{l}\text { 再分散 } \\
30^{\circ}\end{array}$ & \begin{tabular}{|l|} 
再分散 \\
$8^{\circ}$ \\
\end{tabular} & 冷 - & $\rightarrow$ 温 \\
\hline L & 5.9 & 4.1 & (3) $-\mathbf{a}$ & - & (3) - c & (5) & オレシジ & - & - & 黄 & 臭恶い & 0 & 6 & オレ色該）黄 & (3) $\left(\begin{array}{l}\text { (状悲) } \\
\text { (5) }\end{array}\right.$ \\
\hline アスベリンシロップ & 4.8 & 4.4 & (3) -2 & (3) $-\mathrm{a}$ & (2) & (3) $-c$ & $"$ & - & - & " & " & 4 & 6 & " & - \\
\hline イノリンシロップ & 4.5 & 4.9 & (3) $-\mathbf{a}$ & (3) $-c$ & - & (5) & $"$ & - & - & $"$ & $"$ & 0 & 7 & $"$ & (3) $-c \rightarrow$ (5) \\
\hline スルピリン & 5.9 & 5.1 & (3)-c & - & - & (5) & $"$ & - & - & $"$ & $"$ & 0 & 6 & $"$ & (3) $-c \rightarrow$ (5) \\
\hline ビソルボン液 & 4.1 & 3.9 & (3) $-\mathbf{a}$ & - & - & - & $"$ & - & - & - & $"$ & 10 & 6 & - & (3) $-c \rightarrow$ (3)-a \\
\hline フラビタンシロップ & 5.5 & 4.3 & (3) $-\mathbf{a}$ & - & (3) $-c$ & - & $"$ & - & - & 黄 & $"$ & 7 & 7 & オレンジー黄 & - \\
\hline ペリアクチンシロップ & 4.7 & 4.1 & (3) $-\mathbf{a}$ & - & 一 & - & $"$ & - & - & $"$ & $"$ & 13 & 7 & $"$ & (3) $-c \rightarrow$ (3)-a \\
\hline ポポン $\mathrm{S}$ 液 & 4.9 & 4.8 & (3)-c & 一 & - & (5) & $"$ & - & - & $"$ & $"$ & 0 & 6 & $"$ & (3) $-c \rightarrow$ (5) \\
\hline メチルエフェドリン散 & 5.9 & 4.1 & (3) $-\mathbf{a}$ & - & (3)-c & - & $"$ & - & - & " & $"$ & 8 & 6 & $"$ & - \\
\hline レクトーゼシロップ & 5.8 & 4.3 & (3)-a & (3)-c & - & - & $"$ & - & - & $"$ & $n$ & 9 & 6 & $"$ & - \\
\hline
\end{tabular}

注：表 2-a に同じ。

表 2-c セポールドライシロップの実験結果

\begin{tabular}{|c|c|c|c|c|c|c|c|c|c|c|c|c|c|c|c|}
\hline セポールに対して & \multicolumn{2}{|c|}{ pH } & \multicolumn{4}{|c|}{ 獎㴧の状態， $30^{\circ}$} & \multicolumn{4}{|c|}{ 液層部の色, $30^{\circ}$} & \multicolumn{5}{|c|}{7 日 後 の } \\
\hline 配 合 剂 & 直後 & 7日後 & \begin{tabular}{|c|}
3 時 \\
間後 \\
\end{tabular} & 1日後 & 3日後 & 7日後 & 直後 & 1日後 & 3日後 & 7日後 & 味·臭 & \begin{tabular}{|c|} 
再分散 \\
$30^{\circ}$ \\
\end{tabular} & \begin{tabular}{|c|} 
再分散 \\
$8^{\circ}$ \\
\end{tabular} & 冷 - & $\rightarrow$ 温 \\
\hline な & 4.9 & 4.3 & (3) $-a$ & (3) $-c$ & - & - & ピンク & - & - & - & - & 7 & 29 & （色調） & （状热） \\
\hline アスベリンシロップ & 4.8 & 4.4 & (3)-c & - & - & - & オレンジ & - & - & - & - & 2 & 1 & - & - \\
\hline イノリンシロップ & 4.8 & 4.4 & (3) $-a$ & (3) $-c$ & - & - & ピンク & - & - & - & - & 8 & 12 & - & - \\
\hline スルピリン & 5.0 & 4.9 & (3) $-c$ & - & - & (5) & $"$ & - & - & - & 苦い & 0 & 9 & - & (3) $-c \rightarrow$ (5) \\
\hline ビソルボン液 & 4.7 & 4.3 & (3) $-a$ & $\begin{array}{l}\text { (3) - c } \\
\text { (4) }\end{array}$ & (3) $-\mathrm{c}$ & - & $"$ & - & - & - & - & 4 & 5 & - & - \\
\hline フラビタンシロップ & 5.1 & 4.5 & (3) $-a$ & (3) $-c$ & - & - & オレンシ & - & - & - & - & 7 & 16 & - & - \\
\hline ペリアクチンシロップ & 5.0 & 4.4 & (3) - $c$ & (3) $-a$ & $\begin{array}{l}\text { (3)-c } \\
\text { (4) }\end{array}$ & - & ピンク & - & - & - & - & 5 & 5 & - & (3) $-c \rightarrow$ (4) $-c$ \\
\hline ポポン $\mathrm{S}$ 液 & 5.2 & 4.7 & (3) $-c$ & - & (5) & - & 淡褐色 & オレンシ & - & - & 臭悪い & 0 & 7 & - & (3) $-c \rightarrow$ (5) \\
\hline メチルエフェドリン散 & 5.1 & 4.5 & (3) $-a$ & (3) $-c$ & - & - & ピンク & - & - & - & 苦い & 5 & 17 & - & - \\
\hline レクトーゼシロップ & 5.2 & 4.5 & $\begin{array}{l}\text { (3)- }-c \\
\text { (4) }\end{array}$ & (3) $-\mathbf{a}$ & (3) $-c$ & (3)- $c$ & $"$ & - & - & - & - & 6 & 9 & - & - \\
\hline
\end{tabular}

注：表 2-a に同じ 
表 2-d ソルシリン顆粒の実験結果

\begin{tabular}{|c|c|c|c|c|c|c|c|c|c|c|c|c|c|c|c|}
\hline ソルシリンに対して & \multicolumn{2}{|c|}{ p H } & \multicolumn{4}{|c|}{ 獎蚫の状態, $30^{\circ}$} & \multicolumn{4}{|c|}{ 液層部の色, $30^{\circ}$} & \multicolumn{5}{|c|}{7 日 後 の } \\
\hline 配 合 剂 & 直後 & 7日後 & \begin{tabular}{|c|}
3 時 \\
翡後
\end{tabular} & 1 日後 & 3 日後 & 7日後 & 值後 & 1日後 & 3日後 & 7日後 & 味·臭 & \begin{tabular}{|c|} 
再分散 \\
$30^{\circ}$
\end{tabular} & \begin{tabular}{|c} 
再分散 \\
$8^{\circ}$
\end{tabular} & 冷 - & 温 ※ \\
\hline な & 6.1 & 4.8 & (3) $-a$ & - & - & (3) $-c$ & 黄 & - & - & - & - & 12 & 不能 & （色調） & $\begin{array}{c}\text { (状態） } \\
8^{\circ}\end{array}$ \\
\hline アスベリンシロップ & 5.6 & 4.8 & (1) & - & (3) $-a$ & (3) $-c$ & オレンシ & - & - & - & - & 7 & $"$ & - & $\begin{array}{l}\text { 保 } \\
\text { 存 }\end{array}$ \\
\hline イノリンシロップ & 5.3 & 4.7 & (3)- $-a$ & - & (3) $-c$ & - & 黄 & - & - & - & - & 10 & $\prime \prime$ & - & 大 \\
\hline スルピリン & 6.2 & 5.1 & (3) $-a$ & - & (3) $-c$ & (5) & " & - & - & - & - & 0 & $"$ & - & $\begin{array}{l}\text { な } \\
\text { 結 }\end{array}$ \\
\hline ビソルボン液 & 5.4 & 4.6 & (3) $-\mathbf{a}$ & - & (3) $-\mathbf{a}$ & (3) $-c$ & $"$ & - & - & - & - & 23 & " & - & 晶 \\
\hline フラビタンシロップ & 6.1 & 4.9 & (3) $-\mathbf{a}$ & - & - & (3) $-c$ & $" \prime$ & - & - & - & - & 28 & $"$ & - & \\
\hline ベリアクチンシロップ & 5.7 & 4.8 & (3)- $-\mathbf{a}$ & - & - & (3)-c &.$\prime \prime$ & - & - & - . & - & 15 & $" \prime$ & - & \\
\hline ポポン $\mathrm{S}$ 液 & 5.4 & 4.6 & (3)-a & (3)-c & (5) & - & $"$ & - & - & - & - & 0 & ". & - & \\
\hline メチルエフェドリン散 & 6.2 & 4.9 & (3)- $\mathbf{a}$ & - & - & (3) $-c$ & " & - & - & - & - & 26 & $"$ & - & \\
\hline レクトーゼシロッフ & 6.2 & 5.0 & (3)- $\mathbf{a}$ & (3) $\cdots$ & - & - & $"$ & - & - & - & - & 5 & $\prime \prime$ & - & \\
\hline
\end{tabular}

注：表 2-a に同じ

表 2-e バストシリン細籼の尖験結果

\begin{tabular}{|c|c|c|c|c|c|c|c|c|c|c|c|c|c|c|c|}
\hline バストシリンに対して & \multicolumn{2}{|c|}{ pH } & \multicolumn{4}{|c|}{ 晸罚の状態, $30^{\circ}$} & \multicolumn{4}{|c|}{ 液屈部の色, $30^{\circ}$} & \multicolumn{5}{|c|}{7 日 後 の } \\
\hline 配们剂 & 直後 & 7日後 & \begin{tabular}{|c|}
3 時 \\
聞後
\end{tabular} & 1 日後 & 3 日後 & 7日後 & 㨁後 & 1日後 & 3日後 & 7日後 & 味·臭 & \begin{tabular}{|c|} 
再分散 \\
$30^{\circ}$ \\
\end{tabular} & $\begin{array}{l}\text { 再分散 } \\
8^{\circ}\end{array}$ & 冷 - & $\rightarrow$ 温 \\
\hline な & 6.5 & 5.1 & (3)- $c$ & - & - & - & オレンシ & - & - & - & - & 22 & 20 & （色調） & （状热） \\
\hline アスベリンシロッナ & 6.0 & 5.0 & (2) & (3)-c & - & - & $"$ & - & - & - & - & 5 & 1 & - & - \\
\hline イノリンシロップ & 5.6 & 4.9 & (2) $-\mathrm{a}$ & (3)- $c$ & - & - & $\prime \prime$ & - & 黄 & - & - & 28 & 25 & - & - \\
\hline スルピリン & 6.5 & 5.2 & (3)- c & - & - & - & $"$ & - & - & 黄 & - & 15 & 19 & - & - \\
\hline ビソルボン液 & 6.0 & 4.8 & (3)-a & (3)-c & - & - & $"$ & - & - & - & - & 24 & 25 & - & - \\
\hline フラビタンシロップ & 6.4 & 5.1 & (3) $-a$ & (3)-c & - & - & " & - & - & - & - & 22 & 20 & - & - \\
\hline ペリアクチンシロップ & 6.2 & 5.1 & (3)-c & - & - & - & $"$ & - & - & - & - & 19 & 21 & - & - \\
\hline ポポン $\mathrm{S}$ 液 & 5.5 & 不能 & (3) $-a$ & (3) - c & 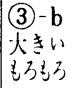 & 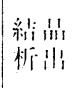 & $"$ & - & - & - & - & 不能 & 21 & - & (3)- $c \rightarrow$ 結晶 \\
\hline メチルエフェドリン散 & 6.5 & 5.2 & (3)-c & - & - & - & $"$ & - & - & - & 苦い & 16 & 14 & - & - \\
\hline レクトーゼシロップ & 6.5 & 5.2 & (3) $-c$ & - & - & - & $"$ & - & - & - & - & 14 & 12 & - & - \\
\hline
\end{tabular}

注：表 2-a に同じ。 
表 2 -f パセトシン細粒の実験結果

\begin{tabular}{|c|c|c|c|c|c|c|c|c|c|c|c|c|c|c|c|}
\hline パセトシンに对して & \multicolumn{2}{|c|}{$\mathrm{pH}$} & \multicolumn{4}{|c|}{ 懸濁の状態, $30^{\circ}$} & \multicolumn{4}{|c|}{ 液層部の色, $30^{\circ}$} & \multicolumn{5}{|c|}{7 日 後 の } \\
\hline 配 合 剂 & 直後 & 7日後 & \begin{tabular}{|l} 
時 \\
間後
\end{tabular} & 1日後 & 3日後 & 7日後 & 直後 & 1日後 & 3日後 & 7日後 & 味·臭 & \begin{tabular}{|c|} 
再分散 \\
$30^{\circ}$ \\
\end{tabular} & \begin{tabular}{|l|} 
再分散 \\
$8^{\circ}$ \\
\end{tabular} & 冷 - & $\rightarrow$ 温 \\
\hline な & 5.6 & 4.7 & (3) $-e$ & - & - & - & 乳白色 & - & - & 黄 & - & 18 & 9 & （色調） & $\sqrt{(\text { (状) }-\mathrm{c} \rightarrow(3)-e}$ \\
\hline アスベリンシロップ & 4.7 & 4.5 & (3) $-\mathbf{e}$ & $\mid$\begin{tabular}{|c|} 
慜濁加 \\
3 層
\end{tabular} & - & (3)-c & 肌色 & オレシシ & - & - & - & 10 & 7 & - & - \\
\hline イノリンシロップ & 4.5 & 4.3 & (3) $-e$ & - & (3)-c & - & 乳白色 & 黄 & - & - & - & 7 & 7 & - & - \\
\hline スルピリン & 5.7 & 5.2 & (3)-e & - & (3)-c & - & $"$ & " & - & - & 一 & 9 & 10 & - & - \\
\hline ビソルボン液 & 4.3 & 4.1 & (3)-e & - & - & (3) $-e$ & $"$ & - & - & 黄 & - & 10 & 8 & - & (3) $-c \rightarrow$ (3)-e \\
\hline フラビタンシロップ & 5.2 & 4.8 & (3) $-e$ & - & - & - & 黄 & - & - & - & - & 13 & 8 & - & (3) $-c \rightarrow$ (3)-e \\
\hline ペリアクチンシロップ & 4.7 & 4.4 & (3)- $e$ & - & - & - & 乳白色 & - & - & 黄 & - & 10 & 9 & - & (3)- $c \rightarrow$ (3)-e \\
\hline ポポン $\mathrm{S}$ 液 & 4.9 & 4.5 & (3)-e & (3)-c & - & - & 黄 & オレッシ & - & - & - & 16 & 10 & - & - \\
\hline メチルエフェドリン散 & 5.6 & 4.5 & (3)-e & - & - & (3)-c & 乳白色 & - & - & 黄 & - & 22 & 9 & - & - \\
\hline レクトーゼシロップ & 5.0 & 4.6 & (3)- $-a$ & - & - & - & " & 黄 & - & - & - & 5 & 6 & - & (3) $-c^{\rightarrow} \stackrel{(3)-a}{4}$ \\
\hline
\end{tabular}

注：表 2-a に同に。

表 $2-\mathrm{g}$ ビクシリンドライシロップの実験結果

\begin{tabular}{|c|c|c|c|c|c|c|c|c|c|c|c|c|c|c|c|}
\hline ビクシリンに対して & \multicolumn{2}{|c|}{ p H } & \multicolumn{4}{|c|}{ 懸濁の状態, $30^{\circ}$} & \multicolumn{4}{|c|}{ 液層部の色, $30^{\circ}$} & \multicolumn{5}{|c|}{7 日 後 の } \\
\hline 配 合 剂 & 直後 & 7日後 & \begin{tabular}{|c|}
3 時 \\
間後
\end{tabular} & 1日後 & 3 日後 & 7日後 & 直後 & 1日後 & 3日後 & 7日後 & 味·臭 & \begin{tabular}{|c|} 
再分散 \\
$30^{\circ}$
\end{tabular} & \begin{tabular}{|l|} 
再分散 \\
$8^{\circ}$
\end{tabular} & 冷 & $\rightarrow$ 温 \\
\hline L & 4.6 & 4.1 & (3) $-e$ & - & (3) $-\mathbf{a}$ & - & 肌色 & - & - & - & - & 30 & 12 & （色調） & (3) $-\mathrm{c} \rightarrow$ (状)- \\
\hline アスペリンシロップ & 4.4 & 4.3 & (3) $-e$ & - & - & - & オレンジ & - & - & - & - & 9 & 10 & - & - \\
\hline イノリンシロップ & 4.3 & 4.3 & (3) $-a$ & (3) $-c$ & - & - & 肌色 & - & 黄 & - & - & 8 & 12 & オレンジ $\rightarrow$ 黄 & - \\
\hline スルピリン & 4.7 & 4.8 & (3) $-e$ & (3) $-c$ & - & - & $"$ & - & - & - & - & 15 & 13 & - & - \\
\hline ビソルボン液， & 4.0 & 4.0 & (3)-c & (3) $-\mathbf{a}$ & - & (3)- $c$ & $"$ & - & - & - & - & 6 & 8 & - & - \\
\hline フラビタンシロップ & 4.7 & 4.3 & (3) $-e$ & - & - & (3) $-\mathrm{a}$ & 黄 & - & オレンシ & - & - & 7 & 11 & - & (3) $-c \rightarrow$ (3)- a \\
\hline ペリアクチンシロップ & 4.4 & 4.3 & (3)-c & (3)- $-b$ & (3)- $c$ & - & 肌 色 & 一 & 黄 & - & - & 7 & 5 & - & - \\
\hline ポポン $\mathrm{S}$ 液 & 4.8 & 4.3 & (3) $-\mathbf{e}$ & (3) $-c$ & - & - & 黄 & オレンジ & - & - & 苦い & 6 & 6 & - & - \\
\hline メチルエフェドリン散 & 4.5 & 4.2 & (3)- $e$ & - & - & (2) & 肌色 & - & - & - & - & 7 & 8 & - & (3) $-c \rightarrow$ (3)- \\
\hline レクトーゼシロップ & 4.5 & 4.3 & $\begin{array}{l}\text { (3) }-e \\
\text { (4) }\end{array}$ & (3) $-b$ & (3) $-\mathbf{a}$ & - & $"$ & 黄 & - & - & - & 7 & 4 & 肌色 $\rightarrow$ 黄 & (3) $-c \rightarrow$ (3) $-a$ \\
\hline
\end{tabular}

注：表 2-a に同じ。 
表 $2-\mathrm{h}$

ビブラマイシンドライシロップの奏䮖結果

\begin{tabular}{|c|c|c|c|c|c|c|c|c|c|c|c|c|c|c|c|}
\hline ヒイラマイシンン柎して & \multicolumn{2}{|c|}{$\mathrm{pH}$} & \multicolumn{4}{|c|}{ 顛濁の状態, $30^{\circ}$} & \multicolumn{4}{|c|}{ 液層部の色, $30^{\circ}$} & \multicolumn{5}{|c|}{7 日 後 の } \\
\hline 配 合 郕 & 直後 & 7日後 & \begin{tabular}{|c|}
3 時 \\
間後
\end{tabular} & 1日後 & 3日後 & 7日後 & 直後 & 1日後 & 3日後 & 7日後 & 味·臭 & \begin{tabular}{|l} 
再分散 \\
$30^{\circ}$
\end{tabular} & $\begin{array}{l}\text { 再分散 } \\
8^{\circ}\end{array}$ & 冷 - & $\rightarrow$ 温 \\
\hline L. & 6.4 & 6.8 & $\begin{array}{l}\text { (3) }-c \\
\text { (4) }\end{array}$ & - & (3)-c & - & 黄 & - & - & - & - & 5 & 4 & (色調) & (3) $-a \rightarrow(3)-c$ \\
\hline アスベリンシロップ & 4.8 & 4.8 & (2) & - & (3)-c & - & オレシシ & - & - & 黄 & - & 2 & 1 & - & - \\
\hline イノリンシロップ & 4.6 & 4.5 & (3)-c & - & - & + & 黄 & - & - & - & - & 3 & 2 & - & - \\
\hline スルピリン & 6.2 & 6.5 & (3)-a & (3)-c & - & - & " & - & - & - & - & 4 & 3 & - & - \\
\hline ビソルボン液 & 4.9 & 4.9 & (3) $-a$ & - & - & (3) $-c$ & $"$ & - & - & - & - & 3 & 3 & - & - \\
\hline フラビタンシロッフ & 5.6 & 5.6 & (3) - a & - & - & (3) $-c$ & " & - & - & オレシシ & - & 3 & 2 & 黄ヤオレンシ & (3) $-a \rightarrow$ (3)-c \\
\hline ペリアクチンシロップ & 5.2 & 5.1 & (3) $-a$ & - & - & (3)-c & " & - & - & - & - & 2 & 3 & - & (3) $-c \rightarrow$ (4) $-c$ \\
\hline ポポン $\mathrm{S}$ 液 & 5.0 & 5.0 & (3) $-a$ & (3)-c & - & - & オレジ & - & - & 褐色 & - & 3 & 3 & オレンジー褐色 & - \\
\hline メチルエエェドリン散 & 6.2 & 6.6 & (3) $-\mathbf{a}$ & - & (3)-c & 一 & 黄 & - & - & - & - & 4 & 3 & - & (3) $-a \rightarrow$ (3)-c \\
\hline レクトーゼシロップ & 6.0 & 5.9 & $\begin{array}{l}\text { (3) }-a \\
\text { (4) }\end{array}$ & - & - & - & " & - & - & - & - & 6 & 4 & - & (3) $-a \rightarrow$ (4) $-a$ \\
\hline
\end{tabular}

注：表 2-a に同し。

つぎに, 表 2 の実験結果の中から味・臭, 再分散性な どについて考察してみた.

7 日間静置したのちの味・臭について調べたものが表 3 である.

表 3 味・臭についての実験結果

\begin{tabular}{|c|c|c|}
\hline 合 & 味 & 臭 \\
\hline エリスロシン一すべての薬㓘 & + & - \\
\hline ケフレックスーすべての薬剤 & - & $0+$ \\
\hline セポールースルピリン末 & $0+$ & - \\
\hline セポールーポポン $\mathrm{S}$ 液 & - & $0+$ \\
\hline セポールーメチルエフェドリン散 & + & - \\
\hline バストシリンーメチルェフェドリン散 & + & - \\
\hline ビクシリンーポポン S 液 ～ & + & - \\
\hline
\end{tabular}

試験した数名の薬阂部員全員が苦い，あるいは臭が悪 いと感したものを+とした。

すなわち, エリスロシンは単味の場合も他剤と配合し た場合も，すべてを苦味を生じまたケフレックスはす べての配合薬において臭が悪くなった. したがって,こ れら+の配合薬を投与すると, 患者が薬剤の服用をいや がる恐れがある.

十の前に○印をつけた配合薬は，30の時にのみ味あ るいは臭が悪くなったもので，80では問題がなかった. したがって, 味・臭に関する限り, 冷所に保存する方が
よいといえる，再分散性についての実験結果を表 4 に示 す.

表 4 再分散についての実験結果

\begin{tabular}{|c|c|c|}
\hline 合 & $30^{\circ}$ & $8^{\circ}$ \\
\hline セポール単味 & - & + \\
\hline ソルシリン単味 & - & H \\
\hline ソルシリンーアスベリンシロップ & - & H \\
\hline ソルシリンーイノリンシロップ & - & H \\
\hline ソルシリンースルピリン末 & - & H \\
\hline ソルシリンービソルボン液 & + & $H$ \\
\hline ソルシリンーフラビタンシロップ & + & H \\
\hline ソルシリンーペリアクチンシロップ & - & $H$ \\
\hline ソルシリンーポポン S 液 & - & $H$ \\
\hline ソルシリンーメチルェフェドリン散 & + & H \\
\hline ソルシリンーレフトーゼシロップ & - & H \\
\hline バストリシリン単味 & + & - \\
\hline バストシリンーイノリンシロップ & + & + \\
\hline バストシリンービソルボン液 & + & + \\
\hline バストシリンーフラビタンシロップ & + & - \\
\hline バストシリンーペリアクチンシロップ & - & + \\
\hline バストシリンーポポン S 液 & H & + \\
\hline パセトシンーメチルェフェドリン散 & + & - \\
\hline ビクシリン単味 & + & - \\
\hline
\end{tabular}

先にあげた方法で，20 回を越える場合を +, 再分散不 
能の場合を\#とした．この表からわかるように, 20 回 を越えるものはバストシリンとの配合に执いて特に多い といえる.な技，外来患者が服用に際して投薬瓶を何回 振っているかを調べたところ，4５回と答えた人が過 半数を占めた. また，振盪に際して底の沈澱物を見てい ない人が約1/4もいることがわかった. したがって，これ ら十の配合薬の服用に際しては, 均一な懸濁液となるま で投薬瓶を充分に振蕰するよう，投与時に特に注意を与 える必要がある.

再分散不能は, $30^{\circ}$ ではバストシリンとポポン $\mathrm{S}$ 液と の配合に捺いてみられた。また，ソルシリンの場合は 8 ○ではすべての配合薬と再分散不能となる.この再分 散不能は，大きい結晶が析出するためであり，いくら振 盪しても温めても溶けない。また，この結晶は早いもの では $8^{\circ}$ で約 4 時間, $20^{\circ}$ でも約 12 時間で析出してくる ので,ソルシリン顆粒を水剂として投与することには問 題がある.

表 5 は $30^{\circ}$ に打ける再分散後の沈澱物を生ずるに要す る時間を調べたものである.

ビクシリンはポポン S 液との配合を除いてすべて 1 分 以内に沈澱する.また $8^{\circ}$ でも 3 分以内に沈澱を生ずる. しかも完全な懸濁の状態ではなく，細粒がふわふわして いるような状態を示す。

表 5 沈降時間についての実験結果

\begin{tabular}{|c|c|}
\hline 1 分以内 & 3 分以内 \\
\hline ビクシリン単味 & $\begin{array}{r}\text { ソルシリンーレフトーゼ } \\
\text { シロップ }\end{array}$ \\
\hline $\begin{array}{r}\text { ビクシリンーアスペリン } \\
\text { シロップ }\end{array}$ & バストシリンーすべての \\
\hline $\begin{array}{r}\text { ビクシリンーイノリン } \\
\text { シロップ }\end{array}$ & ビブラマイシン単味 \\
\hline ビクシリンースルピリン末 & $\begin{array}{r}\text { ビブラマインシーイノリン } \\
\text { シロップ }\end{array}$ \\
\hline ビクシリンービソルボン液 & $\begin{array}{r}\text { ビブラマイシンースル } \\
\text { ピリン末 }\end{array}$ \\
\hline 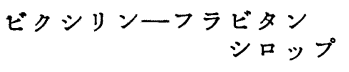 & 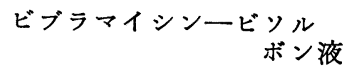 \\
\hline $\begin{array}{r}\text { ビクシリンーペリアクチン } \\
\text { シロップ }\end{array}$ & $\begin{array}{r}\text { ビブラマイシンーフラビタ } \\
\text { ンシロップ }\end{array}$ \\
\hline 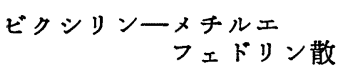 & 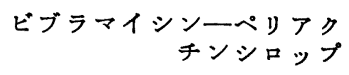 \\
\hline 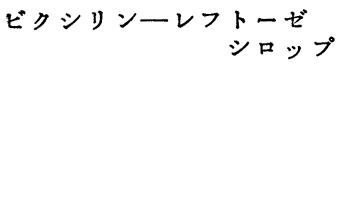 & 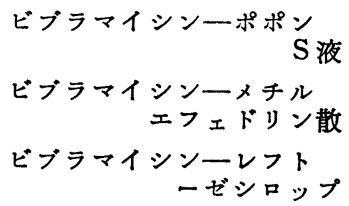 \\
\hline
\end{tabular}

バストシリンは，単味の 場合も含めてどの配合薬と
もまた，ビブラマイシンはアスベリンシロップとの配 合を除いて，すべて 3 分以内に沈澱を生ずる.

したがって，これらの配合薬を患者に服用させる場合 はふふりまぜて直ちに服用させなければならない。一度 ふりまぜて少し時間をおいて服用した場合には，主薬含 量の少い上澄液のみを服用する恐れがある.

液層部の色調に関しては，7 日間の保存中に著しく变 化したものはなかった。 また $\mathrm{pH} に$ 関しても，調剤直後 と 7 日後とを比較した場合，著しく変動したものはな い. 特に $8^{\circ}$ 保存のものは調剤直後とほとんど変わらな いことがわかった.

つぎに，表 6 は同一成分が，製薬会社によりどのよう な違いがあるかを示したものである.

アンピシリンでは, ソルシリンが再分散不能で比較す ることが困難なため, セファレキシンについて検討した.

表 6 セファレキシンの再分散の比較

\begin{tabular}{|c|c|c|c|c|}
\hline \multirow{2}{*}{ 配 合 薬 } & \multicolumn{2}{|c|}{ ケフレックス } & \multicolumn{2}{|c|}{ セポール } \\
\hline & $30^{\circ}$ & $8^{\circ}$ & $30^{\circ}$ & $8^{\circ}$ \\
\hline 単味 & 0 & 6 & 7 & 29 \\
\hline アスベリンシロップ & 4 & 6 & 2 & 1 \\
\hline イノリンシロップ & 0 & 7 & 8 & 12 \\
\hline スルピリン 末 & 0 & 6 & 0 & 9 \\
\hline ビソルボン 液 & 10 & 6 & 4 & 5 \\
\hline フラビタンシロップ & 7 & 7 & 7 & 16 \\
\hline ペリアクチンシロップ & 13 & 7 & 5 & 5 \\
\hline ポ ポ ン $\mathrm{S}$ 液 & 0 & 6 & 0 & 7 \\
\hline メチルェフェドリン散 & 8 & 6 & 5 & 17 \\
\hline レフトーゼシロップ & 9 & 6 & 6 & 9 \\
\hline
\end{tabular}

再分散性をみてみると， $30^{\circ}$ では完全に透明となり， 再分散を必要としないのが，ケフレックスでは 4 組，七 ポールでは 2 組あった.

また 80 の場合, ケフレックスは配合薬の種類によっ て左右されないが，七ポールは 1 回から 29 回と大きな 開さがあった。このように, シャップ斉の調剤において は, 配合薬の種類によって, 抗生物質単味に比べて再分 散性が良くなったり悪くなったりすることがある.

最後に,ビブラマイシンについて, 剤型の違いによっ てどのように異なるかを比較してみた. 表 7 に示すよう に再分散性についてその回数でみた場合, シャップとド ライシロップの間にはほとんど差はない。しかし, 再分 散後ドライシャップはすべての配合薬において，3 分以 内に沈澱を生じるが，シロップではそのようなことはな かった. また，ドライシロップは 7 日間の保存中に味・ 臭とも特に変化はみられないが, シロップでは, イノリ 
表 7 ビブラマイシンの再分散

\begin{tabular}{|c|c|c|c|c|}
\hline \multirow{2}{*}{ 配 } & \multicolumn{2}{|c|}{$\begin{array}{l}\text { ビブラマイシ } \\
\text { ソシ ロップ }\end{array}$} & \multicolumn{2}{|c|}{$\begin{array}{l}\text { ビブラマイシン } \\
\text { ドライシロツフ }\end{array}$} \\
\hline & $30^{\circ}$ & $8^{\circ}$ & $30^{\circ}$ & $8^{\circ}$ \\
\hline 単味 & 2 & 3 & 5 & 4 \\
\hline アスペリンシロップ & 2 & 1 & 2 & 1 \\
\hline イノリンシロップ & 3 & 2 & 3 & 2 \\
\hline スルピリン 末 & 3 & 3 & 4 & 3 \\
\hline ビソルボン 液 & 3 & 3 & 3 & 3 \\
\hline フラビタンシロップ & 3 & 3 & 3 & 2 \\
\hline ペリアクチンシロップ & 3 & 2 & 2 & 3 \\
\hline ポ ポン $\mathrm{S}$ 液 & 2 & 2 & 3 & 3 \\
\hline メチルェフェドリン散 & 3 & 3 & 4 & 3 \\
\hline レフトーゼシロップ & 3 & 3 & 6 & 4 \\
\hline
\end{tabular}

ンシロップおよびメチルェフェドリン散との配合におい て苦味を生じた。

またシロップはポポン S 液と配合した場合, 配合直後 には透明となり，3時間後には大きい沈澱物を生じてく
る.したがって，患者に投与した直後は透明液である が，患者が州宅した頃には沈澱物を生じることになるた め, 患者に不安を抱かせる恐れがある. ドライシロッで はこのようなことはおこらない。

$$
\text { おわりに }
$$

以上のように配合薬の種類によって, 再分散性が非常 に悪くなるものや, 再分散不能となるもの, また再分散 後 1 分以内に沈澱を生ずるものなど, 配合に問題のある ものがかなりある. シャップ剂を用いる患者の多くは乳 幼児であるから，これらの事柄は特に重要な問題であ る.したがって, 調剤する側においては各シロップ剂の 配合変化などについての資料を集め，問題のある配合に ついては，患者に投与する際十分説明する必要があると 考える.

\section{参 考 交 献}

1) 高杉益充他:「薬物療法」8，2529 (1975).

2) 高杉益充他：「薬物療法」8,2791 (1975).

3）高杉益充他：「薬物療法」8,2869 (1975).

\section{扁桃腺炎・只内资}

\section{咽喉頭炎・口内手術創に！}

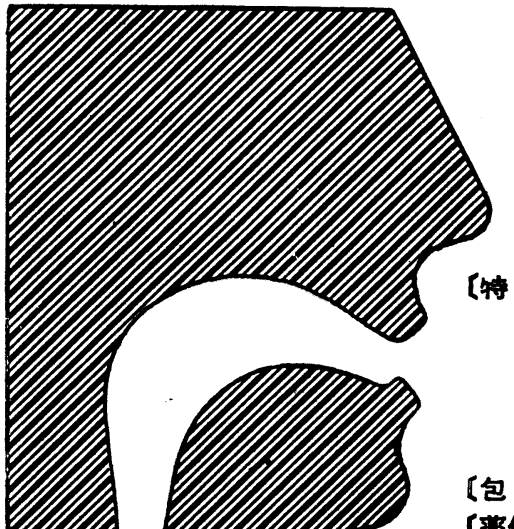

\section{含濑用水溶性}

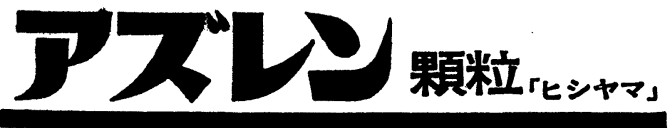

與了○消资、肉芽発生促進作用により口腔内の炎症を 緩解します。

○水を加えると速かに溶解して淡有色のうがい液 となり清涼感があります。

１回贯宛分包されていますから投菜に手間がか からず㩲帯にも便利です。

〔包壮] $2 g \times 100$ 包

$2 g \times 1000$ 包

2 × $\times 2500$ 包

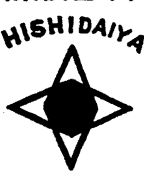

菱山製薬株式会社

大阪市東区道修町 $2-37$ 営業所: 東京・名古屋・福岡・札筧・仙台・広岛・高松 